\title{
PELATIHAN PEMBUKUAN AKUNTANSI SECARA SEDERHANA DAN DIGITAL BAGI KELOMPOK UP2K-PKK DESA SEMBAWA KECAMATAN JALAKSANA
}

\author{
Dadang Suhendar ${ }^{1}$, Dendi Purnama ${ }^{2}$, Neni Nurhayati ${ }^{3}$ \\ 1,2,3Program Studi Akuntansi, Fakultas Ekonomi, Universitas Kuningan \\ Email: dadang.suhendar@uniku.ac.id, dendi.purnama@uniku.ac.id, neni.nurhayati@uniku.ac.id
}

\begin{abstract}
Abstrak
Tujuan dari kegiatan pengabdian masyarakat ini adalah untuk meningkatkan pengetahuan dan keterampilan kepada kelompok UP2K-PKK desa Sembawa dalam melakukan pembukuan akuntansi secara sederhana dan digital. Metode pelaksanaan kegiatan yang digunakan dalam pengabdian ini menggunakan metode pelatihan. Jumlah peserta yang hadir dalam kegiatan pengabdian sebanyak 20 orang anggota kelompok UP2K-PKK Desa Sembawa. Dari hasil kegiatan pengabdian yang telah dilaksanakan bahwa para peserta antusias mengikuti pelatihan pembukuan akuntansi sederhana dan digital. Secara teori sebagian peserta memahami materi yang telah disampaikan oleh pemateri. Namun pada saat praktik mereka mampu memahami dan mempraktikan pembukuan akuntansi sederhana, mengelompokan akun-akun, mengidentifikasi dan menjumlahkan saldo akun-akun yang ada pada aktiva dan pasiva. Pada saat praktik menyusun laporan laba rugi dan laporan keuangan sederha hanya sebagian peserta yang mampu mempraktikan. Selain itu, pada saat praktik mencatat transaksi ke dalam aplikasi akuntansi UKM sebagian peserta mengalami kesulitan dalam mengidentifikasi dan mengelompokan akun-akun yang dipakai dalam setiap transaksi. Namun setelah diberi pemahaman dan didampingi para peserta bisa mencatat kedalam aplikasi akuntansi UKM.
\end{abstract}

\section{PENDAHULUAN}

Pemerintah daerah kabupaten Kuningan mendukung keberadaan kelompok Usaha Peningkatan Pendapatan Keluarga (UP2K)-PKK sebagai salah satu program untuk membantu meningkatkan pendapatan perempuan. Hal ini dibuktikan dengan adanya lomba UP2K tingkat kabupaten Kuningan tahun 2021 yang diselenggarakan oleh pemerintah daerah. (sumber: kuningankab.go.id, 2021). Kegiatan ini untuk mengembangkan usaha keluarga yang tergabung melalui kelompok maupun perorangan dan sebagai penggerak perekonomian desa sehingga secara bertahap diharapkan mampu menjadi wiraswasta yang handal serta meningkatkan tumbuhnya kegiatan yang bersifat kooperatif dalam mewujudkan keluarga yang sejahtera. Selain itu, program ini untuk memperkuat kelompok-kelompok PKK dalam mengelola dan menumbuhkembangkan usaha ekonomi untuk meningkatkan pendapatan keluarga dan meningkatkan peran kader-kader PKK dalam rangka membantu keluargakeluarga agar mampu mewujudkan kesejahteraan hidupnya. 
Dengan adanya kegiatan lomba UP2K-PKK dan dukungan dari pemerintah daerah dapat merangsang dan memotivasi desa-desa untuk menggerakan kelompok UP2K agar terus berkembang dalam memproduksi produk yang berkualitas dengan terus melakukan promosi sehingga omset penjualan usahanya akan meningkat. Selain itu juga adanya kelompok UP2K dapat dijadikan sebagai penggerak ekonomi desa untuk membantu keluarga dan invidu memperoleh penghasilan sehingga dapat mensejahterakan kehidupannya. Namun, keberadaan UP2K masih terus dibina dan dilatih agar terus mandiri dalam menjalankan usahanya karena kebanyakanya kelompok UP2K belum mampu dalam membentuk kelembagaan dan pengelolaan keuangan yang baik.

Dalam kegiatan pengabdian ini, penulis mengambil objek kelompok UP2K di desa Sembawa. Desa Sembawa merupakan salah satu desa di kecamatan Jalaksana. Mereka terus berupaya untuk mengembangkan produk tersebut agar dikenal oleh masyarakat disekitar kecamatan Jalaksana bahkan harapannya dapat dikenal dikabupaten Kuningan maupun luar Kabupaten Kuningan. Selain itu, dalam menjalankan usahanya mereka hanya terfokus pada pemasaran dan produksi dan tidak menganggap penting mengenai pembukuan akuntansi dan pelaporan keuangan. Hal ini didukung berdasarkan survei ke lapangan dengan mewancarai ketua kelompok UP2K-PKK desa Sembawa bahwa anggota kelompok UP2K belum sepenuhnya memahami terkait dengan pembukuan akuntansi maupun pelaporan keuangan. Mereka hanya sebatas mencatat uang masuk dan uang keluar secara tradisional. Kebanyakan anggota kelompok UP2K merupakan ibu-ibu dengan latar pendidikan bukan dari sarjana ekonomi sehingga mereka perlu pelatihan terkait dengan pembukuan akuntansi secara manual dan digital. Dalam menjalankan usaha kelompok UP2K tidak hanya menguasai terkait dengan pembuatan produk maupun pemasaran akan tetapi mereja harus terampil dalam pembukuan akuntansi karena sama pentingnya. Apabila pembukuan akuntansi belum diterapkan dengan benar maka keuntungan yang dihasilkan tidak akan optimal. Apalagi dimasa pandemi covid19 perlu mengatur keuangan usaha dengan baik. Banyak pelaku usaha dimasa pandemic covid19 mengalami kebangkrutan dikarenakan tidak menerapkan pembukuan akuntansi dengan benar. Hal ini sesuai pernyataan Maharani \& Hasanah (2020) masih banyak pelaku usaha yang tidak memperhatikan pengelolaan keuangannya dengan benar, sehingga dalam perjalanan bisnis yang dilakukannya tidak terlihat secara jelas perkembangan usaha baik secara keuntungan ataupun material yang dimiliki. Padahal melalui pembukuan dapat melihat pergerakkan dari perjalanan bisnis yang dilakukan. 
Selain itu, penghasilan yang diperoleh seringkali tidak berimbang dan sebanding dengan pengeluaran mereka, sehingga banyak pelaku usaha mikro yang kehabisan modal usaha tanpa mengetahui ke mana uang tersebut dibelanjakan. Oleh karena itu, dalam rangka menjaga keberlangsungan kegiatan usaha, maka diperlukan pengetahuan, ketrampilan dan sikap perilaku untuk mengelola seluruh aspek usaha dengan baik khususnya di bidang keuangan diperlukan perhatian lebih khusus dan serius. (Layyinaturrobaniyah \& Muizu, 2017).

Pemahaman terhadap pembukuan akuntansi tidak hanya sekedar bagaimana cara mencatat uang kas, namun juga bagaimana cara mengelola keuangan agar keuntungan yang dihasilkan lebih optimal. Kelompok UP2K seharusnya mempunyai buku catatan kas masuk dan juga kas keluar. Penerapan sistem pembukuan akuntansi dapat memberikan informasi mengenai kondisi keuangan perusahaan sehingga kelompok usaha UP2K dapat mengevaluasi mengenai capaian penghasilan dari hasil usahanya melalui laporan laba rugi. Selain itu, dalam kegiatan pengabdian ini mereka dilatih untuk menggunakan aplikasi pembukuan akuntansi secara digital yang bernama aplikasi Akuntansi UKM berbasis android. Hal ini untuk membantu kelompok UP2K PKK dalam menyusun pembukuan akuntansi secara digital. Sudah saatnya pelaku usaha bertransformasi kedalam dunia digital.

Berdasarkan permasalahan di atas penulis tertarik untuk melakukan program pengabdian kepada masyarakat pada kelompok UP2K PKK di Desa Sembawa. Adapun solusi yang dapat diberikan dalam memecahkan permasalahan di atas yaitu memberikan pengetahuan dan keterampilan kepada kelompok UP2K PKK desa Sembawa dalam melakukan melakukan pembukuan akuntansi secara manual yang tepat. Memberikan pengetahuan dan keterampilan kepada kelompok UP2K desa Sembawa dalam melakukan pembukuan akuntansi secara digital. Tujuan dari kegiatan pengabdian masyarakat ini adalah Untuk meningkatkan pengetahuan dan keterampilan kepada kelompok UP2K-PKK desa Sembawa dalam melakukan pembukuan akuntansi secara sederhana dan untuk meningkatkan pengetahuan dan keterampilan kepada kelompok UP2K-PKK Desa Sembawa dalam melakukan pembukuan akuntansi secara digital.

\section{METODE}

Metode pelaksanaan kegiatan yang digunakan dalam pengabdian ini menggunakan metode antara lain: (1) Pelatihan merupakan proses belajar mengajar dengan menggunakan teknik dan metode tertentu secara konsepsional dengan tujuan untuk meningkatkan 
keterampilan dan kemampuan seseorang atau sekelompok orang (Siagian dalam Lubis, 2008). Adapun teknik yang digunakan dalam metode pelatihan ini yaitu: Teknik presentasi informasi yang meliputi ceramah dan diskusi, (2) Pendampingan dilakukan pendekatan klasikal dilakukan pada saat pemberian soal latihan pembukuan akuntansi manual dan digital dalam menggunakan aplikasi akuntansi UKM berbasis android.

Adapun langkah-langkah kegiatan yang dilakukan adalah pelatihan dan pendampingan dengan tahapan sebagai berikut: (1) Pelatihan tentang pembukuan akuntansi secara manual disertai dengan praktik dan (2) pelatihan tentang pembukuan akuntansi secara digital menggunakan aplikasi akuntansi UKM berbasis android disertai dengan praktik. Sedangkan jumlah peserta yang hadir dalam kegiatan pengabdian sebanyak 20 orang anggota kelompok UP2K-PKK Desa Sembawa. Pelaksanaan pengabdian dilaksanakan pada bulan November 2021 diminggu ketiga selama tiga hari.

\section{HASIL DAN PEMBAHASAN}

Kegiatan pengabdian masyarakat dilaksanakan di desa Sembawa kecamatan Jalaksana selama tiga hari. Hasil kegiatan pengabdian ini dapat melatih keterampilan anggota kelompok UP2K-PKK dalam menyusun pembukuan akuntansi hingga pelaporan keuangan secara sederhana dan digital. Mereka antusias dan merespon dengan baik untuk mengikuti Kegiatan ini karena selama ini mereka hanya tidak melakukan pembukuan baik secara sederhana maupun digital dan hanya sepetahuan dan tidak sesuai dengan format atau standar yang ditetapkan. Pembukuan akuntansi ini sangat penting dilakukan oleh pelaku usaha karena mereka dapat melihat informasi mengenai pemasukan dan pengeluaran kas, kondisi keuangan perusahaan, merencanakan keuangan, pengawasan mengenai kas, pengambilan keputusan, menganalisis data keuangan perusahaan serta mengetahui untung atau rugi usaha. Dengan adanya kegiatan ini usaha UP2K akan terarah dan terkendali sehingga usaha yang dijalankan akan memperoleh laba yang diharapkan oleh kelompok UP2K dan dapat meminimalisir kerugian yang ditimbulkan oleh risiko dalam menjalankan usahanya.

Kegiatan pengabdian masyarakat ini memberikan pelatihan mengenai pembukuan akuntansi secara sederhana, dimana para peserta diberikan pengetahuan dan keterampilan bagaimana cara melakukan pembukuan yang tepat, mengelompokan akun-akun aktiva dan pasiva, penjabara/ ikhtisar laba rugi dan pelaporan keuangan. Adapun tahapannya yaitu (1) para peserta diberi pengetahuan dan praktik cara mencatat transaksi kedalam format kolom 
yang sudah disediakan sesuai dengan pembukuan akuntansi sederhana seperti mencatat uang masuk dan uang keluar dalam buku kas. Awalnya para peserta belum paham mengenai pembukuan akuntansi, namun setelah dijelaskan dan adanya pendampingan para peserta mampu memahami pembukuan akuntansi sederhana, (2) para peserta diberi pengetahuan dan praktik cara mengelompokan akun-akun yang terdapat pada aktiva dan pasiva. Awalnya sebagian peserta belum bisa membedakan antara akun-akun aktiva dan pasiva, namun untuk nama-nama akun mereka sudah tahu. Dalam pengelompokan akun-akun, mereka diberi pemahaman untuk mengidentifikasi dan menjumlahkan akun-akun yang ada pada aktiva dan pasiva selama menjalakan usaha. Dengan menyediakan format kolom agar mereka langsung bisa mengisinya. Selain itu, para peserta diberi pemahaman bahwa jumlah aktiva dan pasiva harus sama, jumlah kas dalam pencatatan pembukuan harus sesuai dengan jumlah saldo pada buku kas, dalam tahap para peserta mampu memahami dan dapat mengelompokan nama-nama akun yang ada pada aktiva maupun pasiva, (3) Para peserta diberi pengetahuan dan praktik cara menyusun laporan laba rugi. Mereka sudah menerapkan namun tidak sesuai dengan standar, dan bahkan hanya memasukan penjualan dikurangi biaya-biaya tanpa mengidentifikasi mengenai beban pokok penjulan, dan mengidentifikasi biaya langsung dan biaya tidak langsung secara terperinci. Pada tahap ini para peserta mampu memahami dan mempraktikan sesuai dengan format laporan laba rugi yang dicontohkan dan (4) Para peserta diberi pengetahuan dan praktik dalam menyusun laporan keuangan sederhana, Sebagian peserta masih mengalami kesulitan jika menerapkan laporan keuangan sesuai dengan standar, mereka harus terbiasa dan sering mempraktikan dalam menyusun laporan keuangan sederhana. 


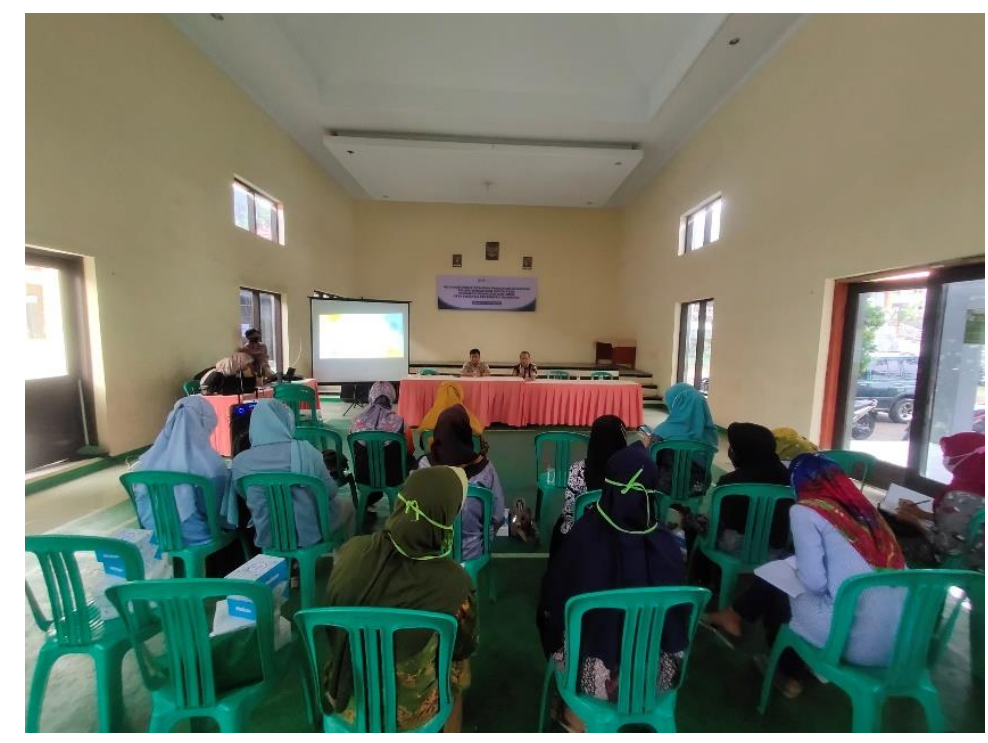

Gambar 1. Pelaksanaan kegiatan pengabdian di Desa Sembawa

Tahap selanjutnya para peserta diberi pelatihan mengenai penggunaan aplikasi akuntansi UKM untuk pembukuan dan pelaporan keuangan secara digital. Dalam tahap ini peserta harus mendownload aplikasi akuntansi UKM pada smartphone mereka. Awalnya mereka mengalami kesulitandan terkendala dalam mendownload aplikasi akuntansi UKM. 


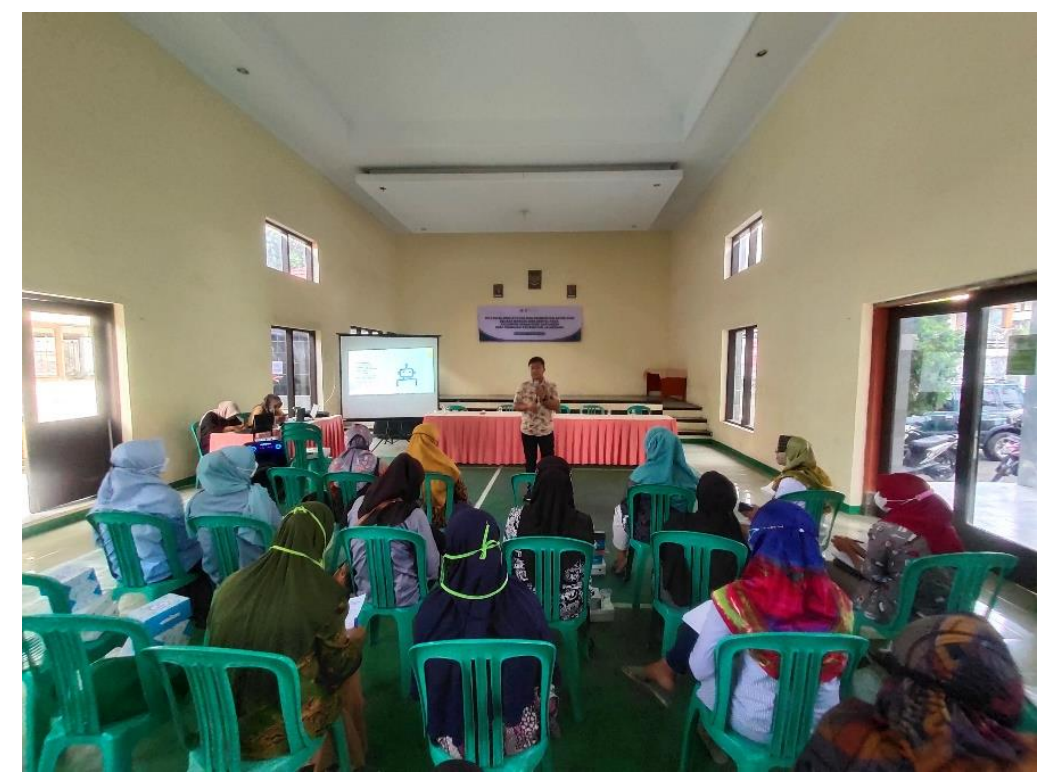

Gambar 2. Pelaksanaan kegiatan pengabdian di Desa Sembawa

Para peserta mempraktikan pembukuan dan pelaporan keuangan digital yang didampingi oleh pemateri. Pada tahap ini mereka langsung mencoba mempraktikan dengan mencatat transaksi ke dalam aplikasi akuntansi UKM. Namun mereka mengalami kesulitan dalam mengidentifikasi dan mengelompokan akun-akun yang dipakai dalam setiap transaksi. Setelah diberi pemahaman dan didampingi para peserta bisa mencatat kedalam aplikasi akuntansi UKM. Para peserta mengganggap penting aplikasi akuntansi UKM untuk digunakan dalam membantu pembukuan dan pelaporan keuangan. Selain itu, aplikasi akuntansi UKM dapat menghasilkan laporan yang dapat didownload dalam bentuk Microsoft excel. 


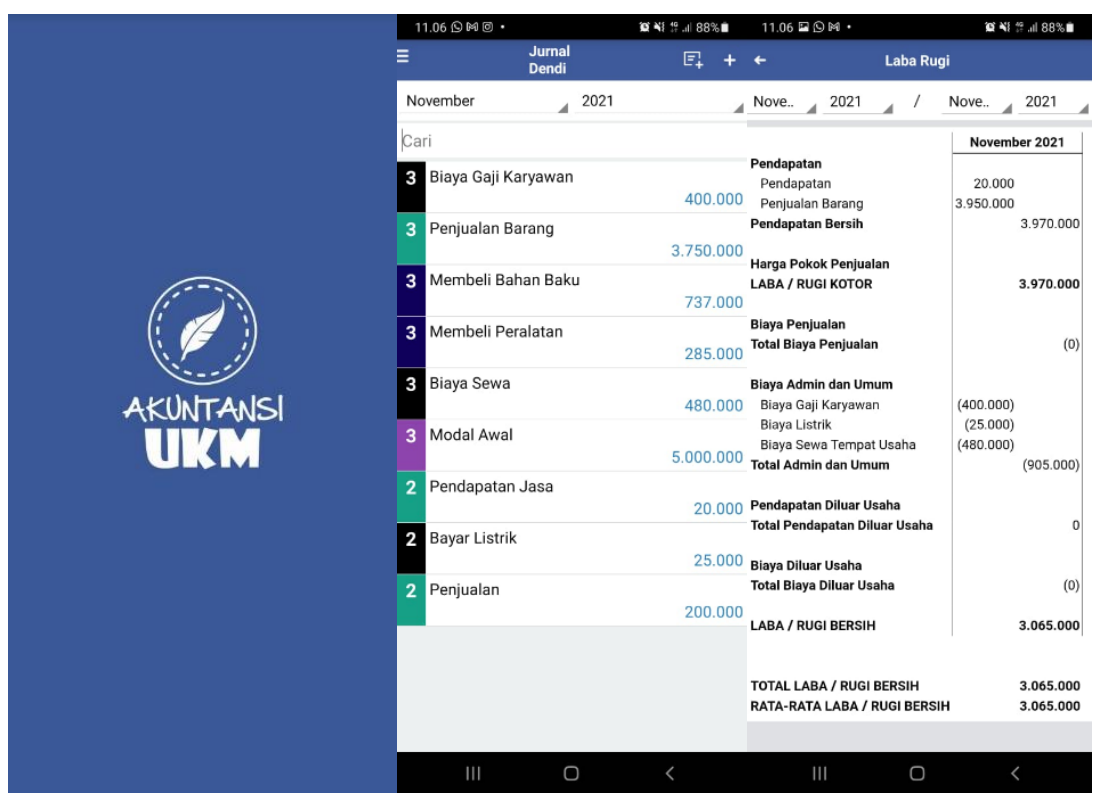

Gambar 3. Aplikasi Akuntansi UKM

\section{KESIMPULAN}

Dari hasil kegiatan pengabdian yang telah dilaksanakan bahwa para peserta antusias mengikuti pelatihan pembukuan akuntansi sederhana dan digital. Secara teori sebagian peserta memahami materi yang telah disampaikan oleh pemateri. Namun pada saat praktik mereka mampu memahami dan mempraktikan pembukuan akuntansi sederhana, mengelompokan akun-akun, mengidentifikasi dan menjumlahkan saldo akun-akun yang ada pada aktiva dan pasiva. Pada saat praktik menyusun laporan laba rugi dan laporan keuangan sederha hanya sebagian peserta yang mampu mempraktikan. Selain itu, pada saat praktik mencatat transaksi ke dalam aplikasi akuntansi UKM sebagian peserta mengalami kesulitan dalam mengidentifikasi dan mengelompokan akun-akun yang dipakai dalam setiap transaksi. Namun setelah diberi pemahaman dan didampingi para peserta bisa mencatat kedalam aplikasi akuntansi UKM. Para peserta mengganggap penting aplikasi akuntansi UKM untuk digunakan dalam membantu pembukuan dan pelaporan keuangan.

\section{SARAN}

Berdasarkan hasil kegiatan pengabdian kepada masyarakat terhadap pelatihan kelompok UP2K-PKK di Desa Sembawa maka saran yang dapat diberikan yaitu agar 
kelompok UP2K-PKK menjadi lebih terampil dalam pembukuan akuntansi sederhana dan digital, perlu adanya pelatihan dan pendampingan yang intens sehingga kedepannya mereka menjadi mahir dan terbiasa.

\section{UCAPAN TERIMA KASIH}

Penulis ucapkan terima kasih kepada Rektor Universitas Kuningan, pelaku usaha Kelompok UP2K-PKK Desa Sembawa, dan Pemerintah Desa Sembawa Kecamatan Jalaksana atas segala dukungan yang telah diberikan sehingga terselenggaranya kegiatan pengabdian ini

\section{DAFTAR PUSTAKA}

Fatwitawati, Reni. 2018. Pengelolaan Keuangan Bagi Usaha Mikro Kecil Menengah (UMKM) Di Kelurahan Airputih Kecamatan Tampan Kota Pekanbaru. Seminar Hasil Pengabdian Kepada Masyarakat, PKN STAN Press, Vol 1, edisi 1.

Layyinaturrobaniyah \& Muizu, Wa Ode Zusnita. 2017. Pendampingan Pengelolaan Keuangan Usaha Mikro Di Desa Purwadadi Barat dan Pasirbungur Kabupaten Subang. Pekbis Jurnal, Vol.9, No. 2, 2017: 91-103

Lembaga Penelitian dan Pengabdian kepada Masyarakat. (2021). Panduan Pengabdian Kepada Masyarakat Hibah Pkm Internal Universitas Kuningan. Kuningan: Universitas Kuningan

Lubis, Irfan Arfan. 2010. Akuntansi Keperilakuan, edisi dua. Salemba Empat: Jakarta

Maharani, Dewi, \& Hasanah, Ikhwatun. 2020. Pelatihan Pembukuan Sederhana Bagi Usaha Kecil Untuk Meningkatkan Pemahaman Pencatatan Keuangan di Desa Puntik Tengah Kecamatan Mandastana Kabupaten Barito Kuala. Ihsan; jurnal pengabdian masyarakat, Vol. 2., No 1.

\section{Sumber lain:}

www.kuningankab.go.id 